\title{
SKAITMENINE் DIPLOMATIJA KAIP ŠVELNIOSIOS GALIOS INSTRUMENTAS EUROPOS SĄJUNGOJE
}

\author{
Mantas Macikas \\ Klaipédos universitetas
}

\begin{abstract}
Anotacija
Interneto vartotojai pasitelkdami skaitmeninès diplomatijos metodus gali generuoti valstybès švelniąją galią socialiniuose tinkluose propaguodami tradicinius galios išteklius - kultūros vertybes ir elgesio pavyzdžius. Taip valstybių skaitmeninė informacijos sklaida tampa jų galios politikos instrumentu. Šiame straipsnyje analizuojama skaitmeninès diplomatijos samprata, jos charakteristikų ir veiklų transformacijos skaitmeninejje erdvejje. Tekste nagrinejjama skaitmeninès diplomatijos ir švelniosios galios sąveika, dėmesys skiriamas Europos Sajungos vykdomai skaitmeninei diplomatijai, kuri yra tapusi svarbia ES užsienio politikos dalimi. Dèl temos naujumo ir tyrimų trūkumo viešajame diskurse straipsnis aktualus moksliniams tyrimams, siekiant išsiaiškinti, kokiais skaitmeninès diplomatijos metodais veikia ES institucijos, diplomatai, pavieniai interneto vartotojai, kaip tai formuoja Europos informacinę geopolitiką.

PAGRINDINIAI ŽODŽIAI: ES, skaitmeninè diplomatija, socialiniai tinklai, švelnioji galia, propaganda.
\end{abstract}

\begin{abstract}
Internet users using digital diplomacy techniques can generate state soft power on social networks through the promotion of traditional power resources - culture, values and behaviour. In this way, the digital dissemination of information by states becomes an instrument of their power policy. This article analyses the concept of digital diplomacy, the transformation of its characteristics and activities in the digital space. The text examines the interaction between digital diplomacy and soft power, also focuses on the European Union's digital diplomacy, which has become an important part of the EU's foreign policy. Due to the novelty of the topic and the lack of research in the public discourse, the article is relevant to research in order to find out what digital diplomacy methods the EU institutions, diplomats, individual Internet users are and how it forms the European information geopolitics.

KEY WORDS: EU, digital diplomacy, social networks, soft power, propaganda.
\end{abstract}

DOI: http://dx.doi.org/10.15181/tbb.v79i3.1894

\section{Ivadas}

Ilgus metus viešosios diplomatijos reiškinys buvo siejamas su tarptautiniais santykiais ir apibrėžiamas kaip pagrindinių užsienio politikos iniciatyvų priedas. XXI a. įsigalejjus internetui, nusistovėjusi viešosios diplomatijos strategija pradèjo kisti, apimdama ne tik ryšių su visuomene ir viešosios komunikacijos sritis, bet ir formuodama naują socialinių tinklų erdvę. Viešoji diplomatija, kuri buvo sparčiai integruota $i$ internetą, tapo neatsiejama socialinių tinklų dalimi. Komunikacija socialiniuose tinkluose, jų dèka ì skaitmeninę erdvę persikèlusi politinè komunikacija bei kintantis valstybių galios pobūdis sudarè palankias skaitmeninès diplo- 
matijos plètros sąlygas. Valstybių institucijos ir interneto vartotojai siekia interesų sklaidos informuodami užsienio auditoriją bei formuodami nuomonę. ES, kaip viena didžiausių tarptautinių santykių veikèjų, sėkmingai naudojasi skaitmeninės diplomatijos priemonėmis, kurios peržengia valstybių sienas. Skaitmeninės diplomatijos tikslas - generuoti valstybès švelniają galią socialiniuose tinkluose. Taigi valstybių skaitmeninè informacijos sklaida tampa jų galios politikos instrumentu. 2014 m. ES turẻjo bẻdų skaitmeninėje erdvėje. Po Krymo aneksijos Rusija pradejjo taikyti informacinio karo metodus. Reaguodama ị padažnejusias informacines atakas skaitmeninèje erdvèje, Europos Komisija padidino skiriamas lëšas iš ES biudžeto kovai su melaginga informacija.

Skaitmeninè diplomatija yra nauja ir gana siaurai tyrinèta komunikacijos forma tarptautinių santykių sistemoje, todèl šio straipsnio tikslas - išnagrinèti skaitmeninès diplomatijos sampratą ES instituciniame veikimo kontekste. Tikslui pasiekti taikomas analitinis metodas leidžia atskleisti skaitmeninès diplomatijos koncepciją ir sampratą, ryšį su švelniaja ES institucinio veikimo galia, išnagrinèti, kokių iššūkių kyla informacinèje erdvèje. Be to, straipsnyje taikomas sisteminis metodas pasiūlymams dẻl ES institucinio lygmens stiprinimo kelti.

\section{Diplomatijos skaitmeninimas - nuo teorijos iki praktikos}

Vykstant Vietnamo karui Jungtinès Valstijos nusprende įsteigti agentūrą, kuri dalintųsi informacija apie savo sprendimų priemimą ir politiką, siekiant telkti visuomenę ir neprarasti įtakos Šaltojo karo metu. Henry’is Kissinger'is šį Šaltojo karo fenomeną aprašè knygoje „Diplomatija“. Jis teigè: „Amerika susidūrè su pačiu dviprasmiškiausiu moraliniu iššūkiu per visą pokario laikotarpị. Kritikus šiurpino televizijos rodomi brutalūs karo vaizdai, jie vis labiau abejojo Amerikos sajungininko Pietų Vietnamo moralumu“ (Kissinger, 2003, p. 723). JAV įvertino šị nepalankų požiūrị ir ieškojo sprendimo, kuris leistų žmonèms tikèti Amerikos išskirtinumu, pasiaukojimu ir tobulumu. Kaip teigia tuometinis prezidento Richard'o Nixon'o patarejas nacionalinio saugumo klausimais H. Kissinger'is, moralinis Amerikos teisuoliškumas trukdè lanksčiai diplomatijai (Kissinger, 2009). Baltieji rūmai bei Kongresas pradejjo ieškoti alternatyvių būdų, kaip spręsti nepalankią situaciją. 1965 m. JAV diplomatas Edmund'as Gullion'as svarbiausioms valstybès institucijoms pasiūlè vartoti viešosios diplomatijos terminą. E. Gullion'o suformuota viešosios diplomatijos koncepcija sukūrẻ galimybę Jungtinèms Valstijoms pradèti efektyviai kontroliuoti informaciją valstybès viduje bei užsienyje.

Siekdamas atskleisti, kaip valstybinès institucijos bendrauja ir sąveikauja tarptautiniu lygiu, James'as der Derian'as pasiūlè technodiplomatijos terminą, mo- 
tyvuodamas tuo, kad valstybėse nykstant tradicinėms kultūroms, žmonių veiksmus diktuoja ekonomiškiausios priemonès (Derian, 2001). Būtent Šaltojo karo pabaiga sutapo su viešosios diplomatijos transformacija. Atsiradęs internetas ilgainiui tapo neatsiejama viešosios diplomatijos raidos dalimi.

2001 m. tuometinis JAV valstybès sekretorius Colin'as Powell'as įsteige elektroninès diplomatijos tarnybą, ambasadas aprūpino internetiniais puslapiais, o JAV diplomatus - išmaniaisiais telefonais (Cull, 2013). Vienu iš viešosios diplomatijos "skaitmenintojų“ tapo JAV valstybès sekretoriaus pavaduotojas, atsakingas už viešają diplomatiją ir viešuosius ryšius James'as Glassman'as. Jo pagrindiniu darbu viešają diplomatiją paverčiant skaitmenine, buvo diplomatų interneto forumų, kuriuose buvo aptariami JAV užsienio politikos ir karo su terorizmu klausimai, stebejjimas. Po keleto bandymų ir stebẻjimų, viešosios diplomatijos, taikančios antrosios kartos interneto technologijas ir socialinès žiniasklaidos priemones, JAV Kongresas prièmė nutarimus, kuriais ịpareigojo valstybės institucijas skaitmenizuotis - komunikacijai naudoti socialinius tinklus.

Remiantis Jan'u Melissen'u, skaitmeninè diplomatija yra diplomatija, aprūpinta ịvairiomis kompiuterinèmis technologijomis, kurios uždaviniai yra stebèti, analizuoti, pranešti bei veikti, siekiant propaguoti šalies interesus (Melissen, 2015). Būtent tokios priemonès diplomatams ir politikams patrauklios dèl nedideliu sąnaudų. Cornel'iu Bjola teigimu, tai ypač aktualu mažoms valstybėms, kurios gali savo komunikaciją perkelti ị aukštesnị lygị, sumažinti atotrūkị nuo didesnių šalių, kurios komunikacijai gali skirti daugiau finansinių išteklių (Bjola, Holmes, 2015). Tai didina mažujų valstybių saugumą, nes leidžia greičiau ir tikslingiau pasiekti norimą auditoriją. Taip per gana trumpą laiką susiformavo nauja viešosios diplomatijos forma - skaitmeninè diplomatija, kuria siekiama spręsti globalias užsienio politikos problemas naudojantis internetu.

Valstybių institucijoms perkèlus ,uždaro kabineto politiką“ i socialinius tinklus, interneto vartotojai dèl informacijos prieinamumo èmé aktyviau domètis politiniais procesais. Todẻl tapo pagrindiniu politikų, naudojančių skaitmenines diplomatijos priemones, taikiniu. Būtina pažymèti, kad augantis internetinių puslapių skaičius išmokè auditoriją atsirinkti: ieškoti labiausiai tapatybę atitinkančio informacijos šaltinio ar net atrasti savo tapatumą, dèl ko išaugo auditorijos nepasitikèjimas tradiciniais informacijos šaltiniais, valstybe ir naujienų agentūromis. Siekdamos susigrąžinti prarastą pasitikèjimą, valstybès ir naujienų agentūros buvo priverstos keisti skaitmeninès diplomatijos strategijas - save pristatyti taip, kaip juos norètu matyti auditorija (Mažeikis, 2006). Būtent ši skaitmeninès diplomatijos koncepcija siekia stiprinti valstybės įvaizdị ir didinti švelniają galią. 


\section{Skaitmeninẻ diplomatija, kaip švelnioji valstybiụ galia}

Komunikacinių technologijų inovacijos bei diplomatijos skaitmeninimas tarptautinèje arenoje priverte politikos lyderius susimąstyti apie tai, kaip kinta valstybių galios pobūdis. Laikotarpis, kai vien karinėmis ir ekonominėmis galios priemonėmis valstybė galèjo nulemti sprendimų priẻmimą, demokratizacijos eroje turi kur kas mažesnị svorị, todèl šiuolaikiniai politikai privalo atrasti kur kas sudètingesnį diplomatinį receptą (Nye, 2004).

Skaitmeninė diplomatija yra valstybių įrankis, pritaikytas greitai kintančiam skaitmeniniam pasauliui. Tos užsienio valstybių tarnybos, kurios tam pasiruoš geriausiai, darys ịtaką tarptautiniams sprendimams. Tam, kad valstybės pasiektų ši tikslą, jos privalo sukurti tinkamą struktūrą ir parengti tinkamas užsienio politikos strategijas (Mellisen, 2007, p. 240). Kad informacija pasiektų auditoriją, valstybė turi skleisti socialinę žinią apie savo vertybes (Hocking, 2017, p. 35). Šis metodas vadinamas švelniaja galia. Joseph'o Nye teigimu, švelnioji galia - tai gebejjimas daryti įtaką pritraukiant ir ịtikinant, o ne priverčiant jèga ar paperkant. Galia remiasi trimis pagrindiniais ištekliais: kultūra, politinèmis vertybẻmis ir užsienio politika (Nye, 2008). J. Nye išskyrè Nyderlandus ir Skandinavijos valstybes, įvardydamas jas kaip šalis, kurių politinè įtaka yra didesnè nei jų karinė galia. Galima teigti, kad skaitmeninè diplomatija pirmiausia apeliuoja ị valstybès švelniosios galios galimybes, siekiant pagrindinių užsienio politikos tikslų, pasitelkus socialinius tinklus. Šie tikslai pateikti 1 paveiksle.

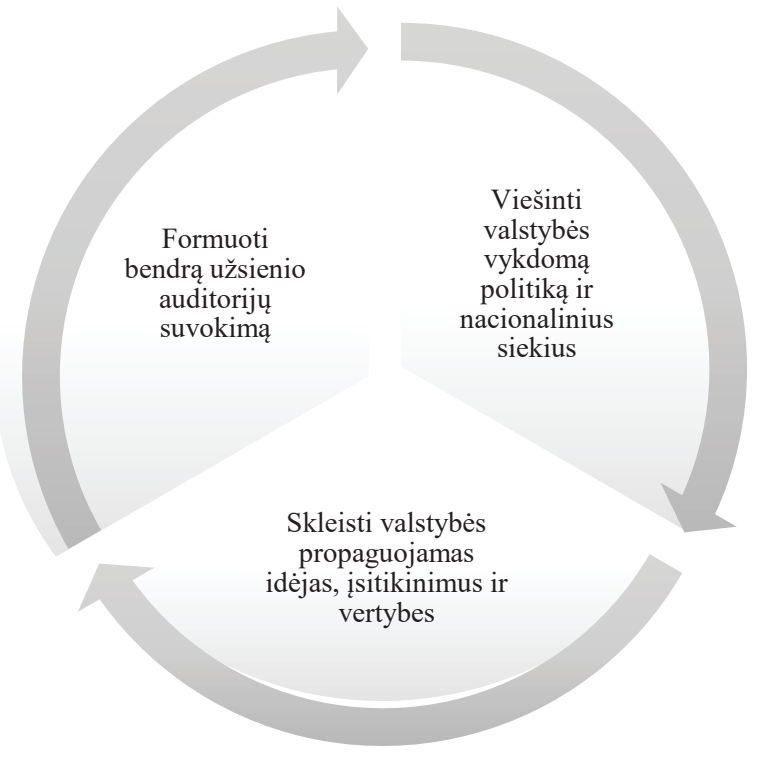

1 pav. Valstybių tikslai, igyvendinami komunikacijos priemonėmis (adaptuota, remiantis Wang, 2006) 
Nors ryšys tarp švelniosios galios ir masinę revoliuciją sukèlusios skaitmeninės diplomatijos iki galo nėra aiškus, švelniosios galios konceptas tapo daugelio autorių skaitmeninės diplomatijos konceptų dalimi. Šiame kontekste J. Melissen'as šią diplomatijos formą apibūdino kaip vieną iš švelniosios galios skatinimo būdų (Melissen, 2007). Pasitelkusi švelniają galią valstybė gali siekti užsienio politikos tikslų. Be to, švelniosios galios privalumas - jei lyderis reprezentuoja vertybes, kurios priimtinos ir kitiems, pasiekti tikslą turètų būti paprasčiau (Melissen, 2007, p. 27).

Anot J. Nye, turima galia ịgalina daryti įtaką kitų elgesiui, siekiant savų tikslų. Tačiau galia nėra vienalypė, yra net keletas būdų, kaip galima paveikti kitų elgesị, paskatinti veikti kitus siekiant naudos (Nye, 2004, p. 32). Galia priklauso nuo esamų tarpusavio santykių konteksto, kuris ir nulemia, koks tikslų siekimo būdas bus taikomas. Kita vertus, galia gali būti suprasta ir kaip elementarus pajègumo bei išteklių valdymas, nulemiantis rezultatus, tikslo ịgyvendinimą. Šiuo atveju valstybė laikoma galinga, jei turi santykinai didelę populiaciją ir teritoriją, valdo daug gamtos išteklių, pasižymi ekonominiu tvirtumu, karinėmis pajėgomis ar socialiniu stabilumu. Toks galios interpretavimas ją sukonkretina ir padaro lengviau išmatuojama bei nuspėjama. Tačiau siekiant užsibrèžto tikslo valstybei nepakanka vien minètus aspektus valdyti, tam būtinos tikslingos strategijos. Atsiranda poreikis derinti valstybės kietąją galią su gebejimu pasitelkti švelniają galią (Snow, 2009).

2017 m. „Monocle“ pateikti švelniosios galios tyrimo duomenys atskleidè, kad iš ES šalių Vokietija yra pirmoje vietoje kaip valstybė, geriausiai naudojanti švelniosios galios priemones. Atliekant ši tyrimą valstybès vertintos pagal jų patrauklumą ir įtaką pasaulio kontekste. Atsižvelgta ị daugiau nei 50 švelniosios galios terminui priskiriamų savybių, iš kurių vienos svarbiausių - valstybès diplomatinè infrastruktūra, kultūros produkcija, išsilavinimo bei verslo galimybės ir olimpinių medalių skaičius. Švelniosios galios lyderių vietas užima didžiosios Europos valstybės: Jungtinė Karalystė, Prancūzija, Švedija ir Italija (Soft Power Survey, 2017).

Jau daugiau nei penkerius metus ịvairių valstybių užsienio reikalų ministrai, diplomatai ar valstybių vadovai aktyviai naudojasi socialiniu tviterio tinklu, siekdami transliuoti savo ir atstovaujamos šalies interesus visuomenei bei taip naudoti valstybès švelniają galią. Tviterio naudojimas igyvendinant užsienio politiką tampa kasdiene praktika: nustatyta daugiau kaip 3500 ambasadų ir ambasadorių, kurie aktyviai naudojasi šiuo socialiniu tinklu. Tviteris tampa neišvengiamu skaitmeninès diplomatijos komunikacijos kanalu (Sandre, 2013, p. 24-36).

Skaitmeninė diplomatija tapo neatsiejamu švelniosios galios įrankiu, pakeitusiu iki tol pasaulyje karaliavusias karines ir ekonomines galios priemones. Svarbus 
vaidmuo akumuliuojant valstybès švelniają galią tenka skaitmeninei diplomatijai. Dèl to dauguma ES valstybiu pastaraisiais metais kuria skaitmeninès diplomatijos padalinius valstybinèse institucijose, gerina ịvaizdị socialiniuose tinkluose ir megzdami ryši su auditorijomis, priiminèja skaitmeninès diplomatijos strategijas.

\section{Skaitmeninė diplomatija ES politinėje sistemoje}

ES išlaiko svarbų vaidmenį geopolitinëje struktūroje, nes tiek teritorine prasme, tiek politinès sistemos reikšmingumu ji gali daryti didelę ịtaką ne tik Bendrijos šalims, bet ir už jos ribų esančioms valstybėms. Šiandien ES yra viena didžiausių skaitmeninès diplomatijos struktūrų pasaulyje, tačiau tam prireikẻ daug laiko ir išteklių. Pirmuoju atsiradusiu internetu naudojosi su švietimu, mokslu ar politika susiję asmenys, bet interneto tinklams plečiantis informacinių technologijų ir kompiuteriu programų kūrimas tapo modernybe, kuria naudojasi ES. Pirmosios technologijos ir internetas ES buvo skirtas šalims susibendrauti tarpusavyje ar greitai persiųsti svarbius dokumentus, o dabar naujosios išmaniosios technologijos ir internetas yra visa apimantis, jo ribos nenustatytos (Fiske de Gouveia, 2005, p. 24). Didèjant ES interneto vartotojų skaičiui, ES viešoji diplomatija persikèlè ị skaitmeninị pasauli. Todèl ES tapo atviresnè visuomenei. Matydama sẻkmę, ji, kaip viena svarbiausių tarptautinių santykių veikèjų, naudodama socialinius tinklus ketina ir toliau sèkmingai plèsti savo įtaką ne tik viduje, bet ir už Sajungos ribų. Europos valstybių užsienio reikalų ministrų pasitarimuose skaitmeninė diplomatija apibrèžta kaip viena reikšmingiausių užsienio politikos veiklų, siekiant plètros ir telkti esamas valstybes (Davis, Mai'a, Melissen, 2013, p. 14-17).

Kaip teigia Ivan'as Rasmussen'as, jau nuo Lisabonos sutarties pasirašymo ES trūksta stiprios jègos, tad jos pagrindinè išorès įtaka yra švelnioji galia, kurią ji atskleidžia skaitmeninès diplomatijos priemonèmis (Rasmussen, 2009). Šiuo metu ES skaitmeninès diplomatijos igyvendinimu užsiima Europos išorès veiksmu tarnyba (EIVT), kuri yra ES diplomatine tarnyba. EIVT vykdo ES užsienio politiką ir siekia didesnès Europos įtakos bei informacinès sklaidos pasaulyje, tačiau 2015 metais kilusi migrantų krizė Europoje tapo rimtu išbandymu šiai organizacijai. Išaugęs informacinių atakų ir melagingų naujienų mastas ES socialiniuose tinkluose priverte EIVT stiprinti strateginès komunikacijos darbo grupes ir ị skaitmeninès diplomatijos plètrą itraukti diplomatus.

Skaitmeniné diplomatija negali veikti be valstybės politikų, diplomatų ir kitų aukšto rango pareigūnų ịsitraukimo ị socialinius tinklus, ryšio su interneto vartotojais užmezgimo. Socialiniuose tinkluose diplomatams tenka dažnai veikti operatyviai: nedelsiant priimti sprendimą, kokią žinutę publikuoti. Nepaisant to, kokius komunikacijos kanalus naudoja kolegos (el. laiškus, dokumentus, skambučius, 
užduotis ar protokolus), EIVT suformavo diplomatams užduotis socialiniuose tinkluose: reikalauta pagerinti kasdienį diplomatų bendravimą visame pasaulyje (Davis, Mai'a, Melissen, 2013, p. 14-17).

S. Duke'as, analizuodamas ES skaitmeninès diplomatijos sudètį, pripažista, kad EIVT, ES šalių diplomatai, pagrindiniai Europos užsienio politikos pareigūnai ir ES delegacijos jau ịsitvirtino socialiniuose tinkluose. Vis dèlto, nepaisant sėkmingų pavyzdžių, ES diplomatijai trūksta nuoseklumo, o tai silpnina tiesiogini dialogą su interneto vartotojais.

Vienas naujausių ịvykių, ịrodęs ES skaitmeninès diplomatijos veiksmingumą, - karas Ukrainoje. 2014 m. aneksavus Krymą ir vykstant karui Rytų Ukrainoje vykdytos Kremliaus kontroliuojamos informacinès atakos socialiniuose tinkluose, nukreiptos prieš Ukrainą ir ES. Reaguodami ị tai ES pareigūnai naudojo tviteri, feisbuką, ir jutubą, pateikdami interneto vartotojams patikrintus faktus bei propagandos demaskavimo metodus. ES tviteris naudojamas dažniau nei feisbukas dèl keleto priežasčių: tviteryje diplomatų paskyros yra aktyvesnès ir turi daugiau sekejjų, pasiekia platesnę auditoriją, be to, šiame socialiniame tinkle publikuojamos žinutės yra trumpos ir patrauklios dèl savo turinio, pranešimais galima dalintis internete ir feisbuko paskyrose (Gurskas, 2015, p. 4-6). 1 lentelëje nurodomi ES institucijų ir Bendrijos narių naudojami socialiniai tinklai, paskyrų skaičius, procentinis ES institucijų ir valstybių ịsitraukimas bei tų puslapių sekejjai-turinio skleidejai (World Leaders on Twitter, 2017).

\section{1 lentelè. Socialinių tinklų naudojimas ES}

\begin{tabular}{|c|c|c|}
\hline Socialinis tinklas & ES institucijų sk. & Sekejai \\
\hline Tviteris (Twitter) & 793 & 325039622 \\
\hline Feisbukas (Facebook) & 569 & 255927669 \\
\hline Instagramas (Instagram) & 300 & 30213526 \\
\hline Linkedinas (Linkedln) & 155 & 5664432 \\
\hline Jutubas (Youtube) & 346 & 3093433 \\
\hline
\end{tabular}

Sudaryta remiantis išvardytų socialinių tinklų analize.

Būdama viešosios politikos dalis, skaitmeninè diplomatija verta daugiau dèmesio ir tyrimų, siekiant surasti atsakymus ị kelis klausimus: ar ES geba nuosekliai veikti savo užsienio politikoje vertikaliu lygmeniu ir kaip ją galima būtų patobulinti, siekiant didinti jos politikos veiksmingumą? Tolesni moksliniai tyrimai gali būti vykdomi skirtingomis kryptimis: ES skaitmeninè diplomatija Pietuose, JAV, Rusijoje ir Kinijoje.

ES skaitmeninė diplomatija turi galimybių taikiomis priemonėmis generuoti valstybès švelniosios galios išteklius internetineje erdveje, todèl apima tik tai- 
kias visuomenès informavimo ir viešujų ryšių sritis, tačiau yra ịpareigota imtis konkrečių veiksmų, įtvirtinant skaitmeninès diplomatijos, valstybinių institucijų ir įmonių informacinį saugumą. Rusijai socialiniuose tinkluose vykdant informacines atakas, ES privalo skaitmeninę diplomatiją traktuoti kaip prioritetą.

\section{Informacinès aplinkos iššūkiai ir galimybès}

Informacinis ES valstybių saugumas tampa sudedamaja visos Europos saugumo dalimi. Disponavimas informacija internete gali daryti ne tik teigiamą, bet ir neigiamą įtaką. Skaitmeninę diplomatiją formuoja diplomatai, teikdami viešus atsakymus ir pasisakydami dèl kitų valstybių, taip darydami ịtaką ir išreikšdami savo netiesioginę galią. Po 2014 m. ịvykdytos Krymo pusiasalio aneksijos Ukrainoje, Rusija, taikydama propagandos metodus, siekia kontroliuoti informacijos srautus ir paveikti visuomenès nuomonę. Iškraipyti faktai pateikiami naudojant įvairias priemones, dažnai yra pritaikyti prie ES valstybių narių ypatybių, siekiant sukelti abejonę, supriešinti Bendrijos nares. Propaganda suvokiama ne tiesiog kaip manipuliavimas verbaliniais simboliais, bet kaip individo ar grupès bandymas patenkinti tam tikrus interesus. Siekiant atpažinti melagingą informaciją būtina išmanyti propagandos technikas (2 pav.).

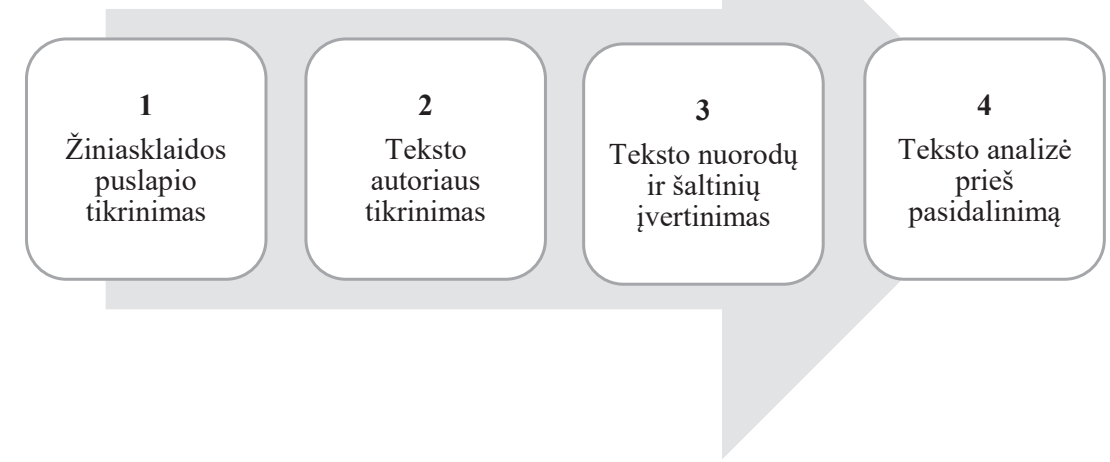

2 pav. Propagandos atpažinimo būdai

Remiantis pateikta informacija, svarbu nustatyti propagandos šaltinị ir kuo tiksliau apibrèžti propagandininko tapatybę. Koordinuotos propagandos šaltinis paprastai yra konkreti institucija arba organizacija, turinti aiškią hierarchinę struktūrą ir lyderị. Propagandininko tapatybę geriausia padeda nustatyti propagandos 
kampanijos ideologijos tyrimas, ypač jei propagandą skleidžia valstybė (Jowett, O’Donnell, 2012).

ES ir Rusijos informacinès konfrontacijos kontekste ypač svarbu taikyti ES apsaugos nuo propagandos ir informacinių atakų mechanizmus. Pastaruoju metu dažniausia kalbama apie techninius informacinio saugumo problemos sprendimo būdus. Siekiant susisteminti analitinius ES skaitmeninės diplomatijos metodus, atliekama SSGG analizè. Nustatomos stipriosios ir silpnosios ES skaitmeninès diplomatijos pusės, galimybės bei grèsmès ES institucinių struktūrų kontekste.

\section{2 lentelè. SSGG analizè}

\begin{tabular}{|c|c|}
\hline Stiprybès & Silpnybės \\
\hline $\begin{array}{l}\text { İtakinga diplomatinè veikla ES ir už jos ribų } \\
\text { Aukšto lygio informacinis raštingumas } \\
\text { ES veikejų patrauklumas socialiniuose } \\
\text { tinkluose } \\
\text { Finansiniai ištekliai } \\
\text { Instituciniai pajègumai }\end{array}$ & $\begin{array}{l}\text { Skirtingas skaitmeninès diplomatijos } \\
\text { prioritetų suvokimas } \\
\text { Vidinis susipriešinimas } \\
\text { Mažèjantis pasitikèjimas naujienų } \\
\text { objektyvumu } \\
\text { Lèta komunikacija su visuomene } \\
\text { socialiniuose tinkluose }\end{array}$ \\
\hline Galimybès & Grèsmès \\
\hline $\begin{array}{l}\text { Visuomenės įtraukimas ị skaitmeninę } \\
\text { diplomatiją } \\
\text { Kompiuteriniai algoritmai, atpažistantys } \\
\text { melagingą informaciją } \\
\text { Skaitmeninės diplomatijos saugumo } \\
\text { strategija } \\
\text { Privaloma diplomatų komunikacija } \\
\text { socialiniuose tinkluose }\end{array}$ & $\begin{array}{l}\text { Rusijos informacinės atakos } \\
\text { Šnipinejjimas socialiniuose tinkluose } \\
\text { ES valstybių diplomatinių santykių krizè } \\
\text { İtaka geopolitiniam mąstymui }\end{array}$ \\
\hline
\end{tabular}

Atlikus apibendrinamają SSGG analizę, suformuotas ES skaitmeninès diplomatijos ir kylančių grèsmių informacijos geopolitikai vaizdas. Pateiktos stiprybės, silpnybės, galimybės ir grèsmės (SSGG) leidžia kritiškai ịvertinti ES perspektyvas. Siekiant sustiprinti ES komunikacini pajegumą, būtina saugoti socialinių tinklų erdves nuo Rusijos informacinių atakų, pasitelkiant nevyriausybinius veikejjus ir patraukliais metodais įtraukiant interneto vartotojus.

\section{Išvados}

Viešoji diplomatija yra neatsiejama kiekvienos valstybès užsienio politikos dalis. Sparčiai besikeičianti diplomatijos forma tapo modernia viešaja diplomatija 
skaitmeninio pobūdžio platformose, kurios plètros ir vystymosi elementu laikomas internetas bei socialiniai tinklai. Socialinių tinklų ir viešosios diplomatijos susitelkimas - skaitmeninè diplomatija - realiu laiku vykdomos valstybių ir užsienio politikos instrumentas, kuris bréžia santykį ne tik su kitomis valstybėmis, bet ir veikia socialinių tinklų platformose, siekiant užmegzti bei palaikyti ryši su visuomene. Skaitmeninès diplomatijos esminè sąlyga - taiki skaitmeninès komunikacijos ir ịtakos forma, kurios skleidejjai ir vykdytojai yra ne tik diplomatai, bet ir eiliniai interneto vartotojai. Taip užtikrinama valstybių švelniosios galios sklaida skaitmeninès diplomatijos priemonèmis.

ES skaitmeninè diplomatija ịgyvendinama kaip vienas reikšmingiausių užsienio politikos uždavinių, siekiant plètros ir esamų valstybių susitelkimo naudojantis socialiniais tinklais. Feisbuko ir tviterio platformose ES diplomatai ir užsienio politikos veikejjai gali bendrauti su visuomene, skleisti informaciją apie ES šalių ir institucijų veiklą, vis dẻlto tokio pobūdžio komunikacija ne visada yra nuosekli. İvertinusi Rusijos keliamą grèsmę ir siekdama užtikrinti informacinị saugumą, ES, pasitelkusi skaitmeninę diplomatiją, siekia dominuoti savo pačios informacinèje erdvejje. ES, siekiant išlaikyti skaitmeninę diplomatiją, kaip saugią valstybių ir piliečių ryšių erdvę, ir apsaugoti informacijos geopolitiką nuo priešiškų valstybių propagandos, būtina ir toliau didinti institucinị pajègumą, formuoti analitikų grupes bei pasitelkti nevyriausybinius veikèjus.

\section{Literatūra}

Bjola, C., Holmes, M. (2015). Digital Diplomacy: Theory and Practice. London: Routledge, p. 28-140.

Cull, N. J. (2013). The Long Road to Public Diplomacy 2.0: The Internet in US Public Diplomacy. International Studies Review, Vol. 5(1), p. 127. Prieiga internete: http://onlinelibrary.wiley.com/doi/ 10.1111/misr.12026/ abstract [žiūrèta 2018-12-02].

Davis, C., Mai’a, K., Melissen, J. (2013). European Public Diplomacy Soft Power at Work. Palgrave Macmillan Series in Global Public Diplomacy, p. 14-17.

Der Derian, J. (2001). Apie diplomatija: Vakaru susvetimejimo geneologija. Vilnius: Eugrimas, p. 283.

Duke, S. (2013). The European External Action Service and Public Diplomacy. Paper of the Netherlands Institute of International Relations. Netherlands: Clingendael, p. 38.

Fiske de Gouveia, P., Plumridge, H. (2005). European Infopolitik: Developing EU Public Diplomacy Strategy. London: The Foreign Policy Centre. Prieiga internete: http://fpc.org.uk/fsblob/657.pdf [žiūrèta 2018-10-27].

Gurskas, M. (2015). Tviplomatija - nauja šiuolaikinės viešosios diplomatijos forma? Politikos mokslu almanachas, p. 4-6. Prieiga internete: https://eltalpykla.vdu.lt/bitstream/handle/1/31246/ISSN2335-7185_2016_V_19. PG_161-180.pdf?sequence=1\&isAllowed=y [žiūrèta 2018-10-29].

Hocking, B. (2017). Rethinking the New Public Diplomacy, p. 35. Prieiga internete: https://www.researchgate. net/publication/304731245_Rethinking_the_New'_Public_Diplomacy [žiūrèta 2018-11-27].

Holmes, M. (2013). What is e-Diplomacy?' Paper presented at 7 th European Consortium for Political Research General Conference, Bordeaux, p. 4.

Jowett, G. S., O’Donnell, V. (2012). Propaganda \& Persuasion. SAGE publications, p. 291.

Kissinger, H. (2003). Diplomatija. Vilnius: Pradai, p. 656.

Kurbalija, J. (2013). E-diplomacy and Diplomatic Law in the Internet Era, p. 15. Prieiga internete: https://www. diplomacy.edu/resources/general/e-diplomacy-and-diplomatic-law-internet-era [žiūrèta 2018-04-27]. 
Mažeikis, G. (2006). Propaganda ir simbolinis mąstymas. Monografija. Vytauto Didžiojo universitetas. Kaunas, p. 345 .

Melissen, J. (2007). The New Public Diplomacy: Soft Power in International Relations. Palgrave Macmillan, p. 240 .

Melissen, J. (2015). Diplomacy in the Digital Age, p. 59. Prieiga internete: https://www.clingendael.org/ [žiūrèta 2017-12-16].

Nye, J. S. (2004). Soft Power: The Means to Success in World Politics. New York: Public Affairs. p. 98-101.

Nye, J. S. (2008). Public Diplomacy and Soft Power. The Annals of the American Academy of Political and Social Science, Vol. 616(1), p. 58.

Rasmussen, I. W. (2009). Towards a Theory of Public Diplomacy: a quantitative study of public diplomacy and soft power. Tufts University, p. 11. Prieiga internete: http://sites.tufts.edu/ivanwr/files/2012/06/A-Theoryof-Public-Diplomacy-Rasmussen-June-2012.pdf [žiūrèta 2018-10-24].

Sandre, A. (2013). Twitter for Diplomats. DiploFoundation and Instituto Diplomatico, p. 24-35.

Snow, N. (2009). Rethinking Public Diplomacy. New York: Routledge, p. 3.

Soft Power Survey 2016/17. (2017). Prieiga internete: https://monocle.com/film/affairs/soft-powersurvey-2016-17/ [žiūrèta 2018-12-03]

Wang, J. (2006). Localising Public Diplomacy: The Role of Sub-National Actors in Nation Branding. Place Branding, Vol. 2(1), p. 32-42. Prieiga internete: https://link.springer.com/article/10.1057/palgrave. pb.5990043 [žiūrèta 2018-12-03].

\section{DIGITAL DIPLOMACY AS A SOFT POWER INSTRUMENT IN THE INSTITUTIONAL ACTIVITIES OF THE EUROPEAN UNION}

\section{Mantas Macikas}

Summary

For more than 10 years, diplomacy and the Internet have been directly related. With the continuous development of digital technologies, social networks, events and news are every day handheld on smart devices, while the rapidly growing number of Internet users and user-generated content have created new dynamics and new digital opportunities. Digital diplomacy is an interactive digital communication process aimed at supporting the state's foreign policy and creating a positive image. When analyzing the relationship between digital diplomacy and digital media, it is necessary to take into account the wider picture: how correlation between social networks and other new public diplomacy platforms is used. In recent years, the use of digital initiatives by foreign ministries is seen as a revolutionary phenomenon in diplomatic practice. In some cases, such a digitalisation of ministries may appear to be late as digital technologies have already been in use for business a long time ago.

For many years, the phenomenon of digital diplomacy has been linked to international relations and is defined as an annex to serve as a major foreign policy initiative. However, in the 21 st century In the course of global digitization, the es- 
tablished strategy of public diplomacy began to change, not only in the spheres of public relations and public communication, but also in the formation of a new area of social networks. Digital diplomacy, which has been rapidly integrated into the Internet, has successfully become an integral part of social networks. Communication in social networks, the political communication that has moved to the digital space, and the changing nature of state power have created favorable conditions for the development and further development of digital diplomacy (Rigalt, 2017). This is because social networks are reaching the Internet users very quickly. Facebook is double the number of Chinese people with its number of users. About 90 percent of the world's 18 to 29 year olds now use social networks, so social networks have become a tool of 21 st century diplomacy to connect with Internet users.

State authorities and Internet users seek to spread interest through informing the foreign audience and forming opinions. Perhaps the most important change is that it is now possible to reach millions of people at the touch of a button. It is for this reason that more and more countries are focusing on alternative forms of communication and encouraging diplomats to use digital technologies and social platforms (Bjola, 2015). The European Union, as one of the major players in international relations, is successfully using digital diplomacy that goes beyond national borders. The goal of digital diplomacy is to generate state power in social networks through the promotion of traditional power resources - culture, values and behavior. In this way, the digital dissemination of information by states becomes an instrument of their power policy.

The use of social networks at institutional level has become an excellent tool for the European Union in the implementation of foreign policy. Social networks have not only reduced the cost of political and public diplomacy, but have also revealed new forms of communication - providing an opportunity to invest in minimal labor, time and money, and communicate directly with Internet users. As the European public sphere of debate is an essential component of the EU, the EU institutions must keep the public informed on social networks.

Digital diplomacy is a new and rather narrowly explored form of communication within the framework of the international relations system, so the aim of this article is to examine the concept of digital diplomacy in the institutional functioning of the European Union. The analytical method used to achieve the goal is to reveal the concept of digital diplomacy, and to formulate tasks to provide the concept of the communication phenomenon scarcely researched by scientists, and the relationship with soft power in the European Union's institutional functioning. There is also a systematic approach to make proposals to strengthen the EU institutional level, empower non-state actors and develop a strategy for effective digital diplomacy. 